\title{
$\underline{\text { Regulation of sclerostin expression by paracrine and endocrine factors }}$
}

A/Prof Natalie A. Sims and Mr Ling Yeong Chia

St. Vincent's Institute of Medical Research, and Department of Medicine at St.

Vincent's Hospital, The University of Melbourne, Fitzroy, Australia 3065

\section{Address for correspondence:}

Natalie A Sims,

St. Vincent's Institute of Medical Research,

9 Princes St,

Fitzroy VIC 3065

Tel: +613-9288-2555

Fax: +613-9416 2676

nsims@svi.edu.au

Keywords: Osteoblast; Osteoclast; Osteocyte; Estradiol; Testosterone;

Sclerostin; Gp130; Ephrin; Biomechanics; Cytokines

Running title: Regulation of Sclerostin 


\section{$\underline{\text { Abstract }}$}

Sclerostin, a secreted protein encoded by the SOST gene has been identified as a key regulator of bone formation by studies in human and mouse genetics. Expression of this protein in osteocytes has been shown to be regulated by mechanical forces; and this has been shown to be critical for the bone formation response to load. Osteocytic expression of sclerostin is also regulated by systemic hormones that are known to influence the skeleton including parathyroid hormone and calcitonin. Circulating levels of sclerostin appear to be influenced by circulating sex steroid levels. Paracrine and autocrine factors expressed by the cells within bone (osteoblasts, osteoclasts and osteocytes), including some members of the family of cytokines that signal through gp130 (oncostatin M, cardiotrophin-1, and leukemia inhibitory factor) as well as prostaglandin $\mathrm{E}_{2}$ rapidly regulate osteocytic sclerostin expression, pointing to new paracrine networks within the bone matrix. In addition, regulation of sclerostin by osteoblastic transcription factors, such as osterix and zinc finger protein 467 have been identified. Finally changes in sclerostin expression due to changes in osteoblast differentiation have been reported in response to inhibitors of ephrin signaling, and in response to the inflammatory mediators tumor necrosis factor and TWEAK. This review will discuss the evidence for each of these influences and what they might mean for bone physiology. 


\section{LIST of ABBREVIATIONS}

$\alpha-C G R P$, Alpha calcitonin gene-related peptide; CNTFR, Ciliary neurotrophic factor receptor; $C T$, Calcitonin; $C T$-1, Cardiotrophin-1; EP, Prostaglandin E series receptors; GnRH, Gonadotrophin-releasing hormone; gp130, glycoprotein 130; IL-33, Interleukin-33; LIF, Leukemia inhibitory factor; LIFR, Leukemia inhibitory factor receptor; $L R P$, Low-density lipoprotein-related protein; $M-C S F$, Macrophage colony stimulating factor; $M E F 2$, Myocyte enhancer factor 2; $O P G$, Osteoprotegerin; OSM, Oncostatin M; OSMR, Oncostatin M receptor; $P T H$, Parathyroid hormone; PTHrP, Parathyroid hormone-related peptide; PTHR1, Parathyroid hormone receptor 1; RANKL, Receptor Activator of $\mathrm{NF}_{\kappa} \mathrm{B}$ Ligand; $s C T$, Salmon calcitonin; $T N F \alpha$, Tumour necrosis factor $\alpha$; TWEAK, TNF-related weak inducer of apoptosis; Zfp467, Zinc finger protein 467.

\section{$\underline{\text { Introduction }}$}

Sclerostin is a secreted protein encoded by the SOST gene that inhibits bone formation. Its importance in human bone biology was discovered when inactivating mutations in this gene, and its downstream regulatory sequences, were both found to cause high bone mass syndromes: sclerosteosis and Van Buchem's disease [1-3]. Similar mutations in genetically altered mouse models each led to similar high bone mass phenotypes, confirming the role of this gene [4-6]. Consistent with these phenotypes, sclerostin has been shown to inhibit osteoblast-mediated mineralization in vitro. The ability of sclerostin to inhibit mineralization appears to relate to its ability to bind LRP5 which thereby blocks its interaction with Frizzled and inhibits Wnt signaling in the osteoblast $[7,8]$, although there are also LRP4-dependent mechanisms at play [9]. 
Sclerostin protein is expressed by osteocytes in mineralized bone, particularly in the most mature osteocytes in cortical $[10,11]$, and calvarial bone [12]. These cells are embedded in the bone matrix, and form a network that likely involves both cell-cell interactions, and release of substances into the canal networks throughout the bone matrix, in which their cellular processes reside, the lacunacanalicular system. While most work to date has focused on the osteocytic expression of sclerostin, sclerostin mRNA has been detected in other organs in human and mouse, including kidney, lung and heart $[1,3,6]$, in vascular smooth muscle cells [13] and human and murine chondrocytes $[3,14]$. At the protein level, elevated expression of sclerostin in adult murine, human and sheep articular cartilage at regions of osteoarthritic damage has been confirmed [15]. Sclerostin protein has also been detected by immunohistochemistry in the subendothelial layer of the adult human aortic intima [2], where it is suspected to inhibit aortic calcification.

Although sclerostin expression is not restricted to osteocytes, the high bone mass phenotype of patients with low sclerostin expression has made inactivation of sclerostin a promising therapeutic approach. To date, it has been shown that neutralizing antibodies to sclerostin increase bone formation, bone mass and bone strength in rodent and primate preclinical models at all skeletal sites examined $[5,16,17]$. This early data also indicates that sclerostin inhibition is able to uncouple the increase in bone resorption usually associated with increased bone formation, which may indicate improved clinical efficacy of this agent compared to other treatments currently available. 
The physiological importance of sclerostin is underscored by its regulation by a wide range of factors that influence bone formation, including hormones, cytokines, mechanical forces, and disorders of the skeleton. This review will be concerned with what is known about the regulation of sclerostin expression in osteocytes and osteocyte-like cells in vivo and in vitro, and what this may reveal about physiological actions of sclerostin.

\section{Influence of mechanical forces on sclerostin expression}

Mechanical forces experienced by the skeleton, whether through exercise or experimental loading, induce bone formation $[15,18]$. Cyclical experimental loading dramatically decreased sclerostin mRNA levels, and profoundly decreased the number of sclerostin positive osteocytes in cortical bone 24 hours after mechanical loading [19]. This effect was more pronounced in regions under most strain, and of highest bone formation levels [19]. More recent work has established that osteocytes within remodeling trabecular bone also respond to loading with a reduction in sclerostin expression and increase in bone mass in this region [20]. This data, and the inhibition of LRP5 signalling by sclerostin are consistent with earlier data showing an impaired bone formation response to experimental loading in LRP5-deficient mice [15].

While mechanical loading increases bone formation, a lack of mechanical forces due to disuse results in bone loss, in part due to reduced bone formation. Immobilization also modifies sclerostin expression. Sciatic neurectomy, a mouse 
model of experimental paralysis, led to a significant increase in sclerostin positive osteocytes [20]. In contrast to the region-specific reduction in sclerostin induced by mechanical loading, the effect of disuse on sclerostin expression was uniform throughout the unloaded bone [20]. In murine tail-suspension models of disuse, sclerostin mRNA levels were significantly increased, but this difference could not be detected at the protein level $[19,21]$. Although circulating sclerostin levels may not reflect only osteocytic changes in sclerostin, in postmenopausal women immobilized by stroke, serum sclerostin levels were significantly greater than in a cohort of mobile postmenopausal women [9], consistent with the increased osteocytic sclerostin observed in murine models of disuse. Sclerostin appears to be absolutely required for the bone loss associated with disuse, since sclerostin-null mice demonstrated no bone loss or reduction in bone formation in a tail-suspension model [4], and anti-sclerostin treatment was able to overcome the bone loss associated with tail-suspension in rats [22].

Inhibition of sclerostin by mechanical loading provides a mechanism for the much older hypothesis that osteocytes, by virtue of their position within the bone matrix are well-situated to respond to mechanical forces and act as signaltransducers to bone forming osteoblasts on the bone surface. In vitro work also supports this model. In a rat osteosarcoma cell line which express high levels of sclerostin (UMR106.01), oscillatory fluid flow, mimicking cyclic bone loading, transiently reduced sclerostin mRNA and protein levels [23]. Reduced sclerostin secretion by osteocytes into the lacunacanalicular system in loaded bone might release osteoblasts from a sclerostin-imposed tonic inhibition to allow increased bone formation at sites of highest strain. The mechanism by which the sclerostin 
can be targeted to particular sites through the extensive, and multidirectional, lacunacanalicular system remains obscure. So too, does the mechanism by which sclerostin is inhibited by mechanical stimulation, but this may relate to an influence of paracrine factors such as prostaglandins, nitric oxide or oncostatin M which rapidly decrease sclerostin expression, and are known early responses to mechanical stimulation [24-26] (see below).

\section{Influence of systemic hormones on sclerostin expression}

Parathyroid hormone (PTH) (via PTH1R)

Parathyroid hormone (PTH) is released by the parathyroid glands as an 84 amino acid peptide in response to hypocalcemia [27], and has both catabolic (i.e. bone destructive) and anabolic (i.e. bone building) effects in bone depending on its mode of administration. Chronic elevation of PTH increases osteoclast formation by actions on osteoblast lineage cells that express PTH receptor 1 (PTHR1) [28]. This action increases production of Receptor Activator of NFKB Ligand (RANKL) and macrophage colony stimulating factor (M-CSF) and suppresses the RANKL decoy receptor osteoprotegerin (OPG) [29-31], thus increasing osteoclast formation. Paradoxically, intermittent elevation of PTH (e.g. by daily injection) promotes osteoblastic precursor proliferation [32, 33], survival of osteoblasts [34, 35], enhances osteoblast differentiation and activity [36] and may also reactivate bone lining cells [37]. This property of PTH has led to its use as an anabolic therapy for bone $[38,39]$. 
Another possible mechanism by which PTH stimulates bone formation is by suppressing sclerostin expression. This action of PTH has been demonstrated both in vivo and in vitro [12], and despite their different effects on bone mass, both continuous and daily injections of PTH in mice reduce osteocytic sclerostin expression [40]. The nature of the change in sclerostin expression was slightly different: with continuous infusion, sclerostin mRNA progressively declined, while a single injection resulted in a transient reduction [40], a difference in timing which has also been reported for PTH action on OPG, and (in the opposite direction) for RANKL [41]. Furthermore, in postmenopausal women circulating sclerostin and PTH levels are negatively correlated [42].

The key to the mechanism by which PTH influences sclerostin expression was those downstream regulatory sequences of the SOST gene that are deleted in Van Buchem's disease $[2,43]$. This conserved 255bp sequence, which is required for sclerostin expression in adult bone, acts as a bone-specific enhancer for SOST gene expression [6]. This region is regulated by the myocyte enhancer factor 2 (MEF2) transcription factors in a manner independent of the proximal SOST promoter region [44]. In osteocytes, MEF2A, B, C and D and sclerostin colocalize, and the activity of the SOST enhancer region was elevated when MEF2C was overexpressed and was inhibited by co-expression of dominant negative or siRNA for MEF2C [44]. This is not the only action of the MEF2 factors; they also regulate myocyte, neuron and immune cell differentiation, and craniofacial development [45-47]. 
PTHR1 also acts as the receptor for a second protein, parathyroid hormonerelated protein (PTHrP), which shares some homology with PTH in the PTHR1 binding region. This protein is not normally found at high levels in the circulation, but it is expressed in bone by osteoblasts and osteocytes, and its expression by the osteoblast lineage is required for normal bone mass [48], indicating that PTHrP may act as the paracrine equivalent of PTH [49]. Both PTH and PTHrP signal through the same receptor (PTHR1). Like PTH, PTHrP also significantly inhibits sclerostin expression in vitro (Walker EC, Ho PWM, Martin TJ, Sims NA, unpublished observations). Genetic ablation of the common receptor for both PTH and PTHR1 using an osteocyte-specific cre recombinase resulted in a higher than usual level of sclerostin expression, and ablated the sclerostin response to PTH treatment [50]. Conversely, transgenic mice that express constitutively active PTHR1 specifically in osteocytes demonstrated a much lower level of sclerostin expression [51, 52].

Work with genetically altered mice has suggested that sclerostin regulation contributes to PTH anabolic action [53]. Consistent with the inhibitory action of sclerostin, transgenic mice overexpressing wild type human sclerostin develop osteopenia with age [6]. When these mice were treated with a high dose anabolic PTH regimen trabecular bone volume was not increased although the dose used was sufficient to increase trabecular bone volume and suppress endogenous SOST mRNA in wild type mice. This demonstrated that over-expression of SOST impaired the full bone anabolic action of PTH. Parameters of bone formation were still significantly increased in the PTH-treated sclerostin-overexpressing 
mice, but less so than in wild type mice. The anabolic action of PTH on both bone mass and bone formation rate was completely blocked in young sclerostin knockout mice [53], treated before the high bone mass phenotype characteristic of the strain became obvious. More recent work has indicated that the dependence of PTH anabolic action on the presence of sclerostin is restricted to the cortical bone [42], so the necessity of PTH-regulated sclerostin in trabecular bone remains controversial.

\section{Calcitonin (CT)}

Calcitonin (CT) is a systemic hormone, with as yet, a still unknown physiological role, even though it was identified 50 years ago as a potent pharmacological hypocalcemic agent [54] due to its rapid inhibition of osteoclast activity $[55,56]$. The high level of calcitonin receptor expression in bone-resorbing osteoclasts has led to its use as a highly specific marker for these haemopoietic lineage cells [57], thus completely unrelated to stromal cell derived osteocytes.

In our recent studies to determine whether active osteoclasts are required for anabolic PTH action, we co-administrated a low dose of salmon calcitonin (sCT) to young rats that received daily PTH anabolic treatment [58]. This co-treatment strategy significantly inhibited PTH anabolic effects, but this was not the only effect. Surprisingly, sCT treatment rapidly increased sclerostin mRNA levels in whole bone, and increased the number of sclerostin positive osteocytes in cortical bone. We then determined that osteocytes freshly isolated from murine calvarial bone expressed calcitonin receptor mRNA [58]. At the same time, a 
microarray study of osteocytes tagged by fluorescent markers also detected a higher level of calcitonin receptor mRNA in osteocytes compared to osteoblasts [59]. Together this suggests that CT may directly stimulate sclerostin expression in the osteocyte, although the mechanism by which this occurs remains obscure due to the difficulty of studying osteocytes in situ.

The physiological role of CT has long been debated, but because of its rapid inhibitory action on osteoclasts, it was thought to be the physiological opposite of PTH. It was surprising then when mice null for the gene that encodes both CT and the calcitonin gene related peptide demonstrated increased bone mass and increased bone formation rate [60]. This increase in bone formation was inferred as caused by the loss of CT, since increased bone formation was not observed in $\alpha$ CGRP-/- mice [61]. Furthermore, mice haploinsufficient for CTR also exhibited increased bone mass and bone formation [62]. The embryonic lethality of CTR-/mice led Davey et al [63] to generate viable global CTR knockdown mice, in which the CTR is reduced $>94 \%$. These mice also displayed a mild increase in bone formation rate. Recent findings reported in abstract form [64] report a new viable global CTR null mouse strain which again demonstrated increased bone formation rate, with gene dose-dependence in heterozygotes. Thus, CT may play a physiological role to reduce bone formation; its stimulatory effect on osteocytic expression of sclerostin could provide a mechanism by which this occurs.

Sex steroids 
Sex steroids, including estrogen and testosterone, are well known to be critical regulators of both bone growth and bone remodeling (for review, see ref [65]), and reduced sex steroid levels after the menopause contribute to postmenopausal osteoporosis, one of the most common disorders of the skeleton. Despite this, the precise mechanism of how these hormones contribute to bone remodeling remains unclear.

Studies in ovariectomized rats and mice have not yet revealed any clear link between sclerostin expression in osteocytes and sex-steroid deficiency [66]. The influences of estrogen and testosterone on sclerostin expression have largely been explored in human studies that have assessed changes in sclerostin protein levels in the circulation, but whether circulating sclerostin reflects release from osteocytes remains unclear. It should also be noted that the assays for circulating sclerostin are still in being developed, so conclusions about absolute levels in the serum, or the magnitude of responses currently detected might have to await validation.

It has been reported that serum sclerostin levels are significantly higher in postmenopausal women compared to premenopausal women, and free estrogen index was negatively correlated with serum sclerostin levels [42]. Consistent with this cross-sectional report, two intervention studies by the same group reported that early postmenopausal women treated with $17 \beta$-estradiol for 4 weeks, demonstrated a significant reduction in circulating and bone marrow plasma sclerostin levels $[20,66]$. Similar results were obtained in elderly men treated with gonadotropin-releasing hormone $(\mathrm{GnRH})$ agonist and $37.5 \mu \mathrm{g} /$ day 
$17 \beta$-estradiol, while men receiving GnRH agonist and 5mg/day testosterone demonstrated increased circulating sclerostin [66]. The correlation of circulating sclerostin levels with bone resorption markers observed in this study [66] is consistent with the decreased bone resorption detected in postmenopausal women, and ovariectomized rats, treated with a neutralizing antibody to sclerostin $[17,67]$.

The causative relationship between circulating sclerostin and sex steroid hormones is unclear, as is the relationship between circulating sclerostin levels and osteocytic sclerostin production. Given the requirement for sclerostin in the effects of mechanical stimulation on bone formation (see above), it is possible that the impaired bone formation in estrogen receptor alpha null mice both at basal levels [68] and in response to mechanical stimulation [69] may involve altered osteocytic expression of sclerostin. Consistent with mechanical sensitivity relating to sclerostin expression, the increase in sclerostin-expressing osteocytes in response to mechanical loads was mildly enhanced in androgenreceptor knockout mice [70] a strain known to be more sensitive to mechanical loading than wild type.

\section{Cytokines and other paracrine factors}

Control of bone mass by locally acting factors, including cytokines and growth factors, is now understood as a major physiological system by which skeletal structure is modified. These local factors are synthesized and released by osteoblasts, osteocytes, and osteoclasts, as well as other cells in the bone marrow 
microenvironment [71]. In addition, some growth factors are released from bone by the resorptive actions of osteoclasts [72].

Oncostatin M, Cardiotrophin-1, and Leukemia Inhibitory Factor

Three cytokines that signal by forming a complex with the ubiquitously expressed co-receptor subunit glycoprotein 130 (gp130), oncostatin M (OSM), leukemia inhibitory factor (LIF) and cardiotrophin (CT-1) have each been shown to inhibit sclerostin expression in cultured osteocytes and, in the case of OSM, when injected in vivo [73]. Inhibition of sclerostin by these agents is rapid, occurring within 6 hours of administration in vitro, consistent with anabolic effects of each of these agents in vivo [73-75].

Each of these cytokines is expressed locally by specific populations of cells within bone: OSM is expressed by osteoblasts and osteocytes [73], LIF is expressed by osteoblasts [76], and CT-1 is expressed by osteoclasts [74] indicating specific communication networks by which they may regulate bone formation. In addition, both OSM and LIF have been implicated in the dysregulation of bone remodeling associated with inflammatory arthritis (for review see [77]). This indicates that cytokines produced locally within bone, or the bone and joint microenvironment can influence osteocytic gene expression and may thereby influence bone formation. Indeed, when CT-1, OSM or LIF are deleted by mouse genetics, a low level of bone formation is observed $[73,74,78]$, showing that these cytokines are clearly also important for maintaining bone formation in normal physiology. 
The inhibition of sclerostin by each of these cytokines is mediated by binding of the cytokine to similar receptor components: gp130 and the LIFR [73]. LIFRdependent inhibition of sclerostin by OSM seems to be sufficient to enhance bone formation in a calvarial injection model even though OSM also promotes expression of pro-osteoblastic transcription factors through a different receptor complex utilizing an OSM-specific receptor (OSMR) which also binds to gp130 [73]. This, like the sclerosteosis phenotype, provides an indication that downregulation of sclerostin is sufficient to promote bone formation on periosteal surfaces. More recent work has suggested that inhibition of sclerostin by OSM and PTH may involve interleukin-33 and its receptor, both of which are upregulated by OSM and PTH within the osteoblast lineage, since IL-33 has been shown to inhibit sclerostin in vitro [8]. It should be noted that cytokines that signal through another complex that includes not only LIFR:gp130 but also CNTFR do not modify sclerostin expression [79].

\section{Prostaglandin $E_{2}$ and hypoxia}

Prostaglandins regulate osteoblast progenitor proliferation and differentiation and act both through cAMP and G-protein coupled signaling [80]. In addition, changes in bone formation in response to mechanical load are likely to depend on local changes in prostaglandin production by the osteocyte, a response that occurs in response to shear stress on the cell sensed by osteocytic cilia [22]. Crosstalk also exists between prostaglandins and the Wnt/ $\beta$-catenin pathway in osteocytes, by which sclerostin regulates bone formation [22]. More recent work 
has shown that prostaglandin $\mathrm{E}_{2}$ itself rapidly inhibits sclerostin expression in the UMR106-01 cell line, through a cyclic AMP/PKA-dependent pathway, but independent of MEF2C transcription factors, therefore distinct from the mechanism by which PTH regulates sclerostin [81]. Prostaglandin E2 acts through two receptors (EP2 and EP4) and receptor specific blockade indicated that sclerostin regulation by prostaglandin E2 is mediated through the EP4 receptor. As mentioned above, this downregulation of sclerostin by prostaglandins may play a role in the mechanical stimulation of bone formation.

Another condition that regulates sclerostin is hypoxia, which has been reported to inhibit sclerostin expression and upregulate beta-catenin signaling in UMR106.01 cells, like PTH, in a MEF2C-dependent manner [82]. This effect was not observed in human embryonic kidney (HEK293) cells, suggesting that hypoxic suppression of sclerostin might be specific to osteogenic cells, although it may also be limited by the much lower level expression of sclerostin in the kidney cell line. The possible importance of hypoxic inhibition of osteocytic sclerostin remains obscure.

Tumor necrosis factor (TNF)

Treatment of human primary osteoblasts, MC3T3-E1 and MG-63 cells with tumour necrosis factor (TNF) and the TNF-related weak inducer of apoptosis (TWEAK) induced sclerostin expression in an ERK-dependent manner [83]. This upregulation may not be a rapid effect, as reported for the cytokines listed above, since changes in sclerostin levels were generally reported only after 72 hours of 
treatment. Since elevated sclerostin expression may also indicate a more rapid progression of osteoblast differentiation this data may indicate that maturing osteoblasts and early osteocytes might be induced, by TWEAK or TNF to progress to the stage of sclerostin expression in an accelerated manner under inflammatory conditions. This regulation may play a role in the local inhibition of bone formation and Wnt signaling reported in mouse models of inflammatory arthritis [84, 85].

\section{Zfp467, ephrinB2 and osterix}

Modulation of sclerostin expression by factors that alter the programme of osteoblast differentiation has also been observed. One factor that regulates this is the transcription factor Zfp467 (Zinc finger protein 467). This factor is expressed ubiquitously and in osteoblasts is inhibited by PTH, OSM and CT-1 [86]. Overexpression of Zfp467 in stromal cells favoured adipocyte differentiation over osteoblast differentiation, and in doing so delayed expression of several late osteoblast marker genes, including PTH receptor 1, osteocalcin, and sclerostin [86]. Another factor that is expressed by osteoblasts and regulates osteoblast differentiation, and thereby influences sclerostin expression is ephrinB2. EphrinB2 is a receptor tyrosine kinase expressed by osteoblasts and osteocytes that appears to be required for late stages of osteoblast differentiation. When cultured osteoblasts were treated specific inhibitors of the interaction between ephrinB2 and one of its receptors, EphB4, the ability of these cells to form mineralized nodules in vitro was impaired as was their expression of late osteoblastic genes including osteocalcin and 
sclerostin $[87,88]$. Neither Zfp467 nor EphrinB2 induce rapid changes in

sclerostin. Rather, the change in sclerostin expression likely relates to a delay in osteoblast differentiation. In this case therefore, sclerostin expression in vitro is an indicator of osteoblast / osteocyte maturation.

Osterix is a transcription factor that is absolutely required for osteoblast differentiation and is expressed at early stages of osteoblast commitment [89]. Since sclerostin is expressed by osteoblasts that have reached the osteocytic stage, it was not surprising that osteoblast-null osterix knockout mice did not express sclerostin [90]. What is surprising though is that this early osteoblastic factor binds to the sclerostin promoter, thereby directly stimulating sclerostin expression; whether this mechanism plays an important role in continued differentiation of the osteoblast lineage remains to be understood.

\section{Clinical implications of osteocytic sclerostin regulation}

Since inhibition of sclerostin by either paracrine, endocrine or genetic alterations results in increased bone formation and bone mass, therapeutic strategies to inhibit sclerostin have been developed. Therapies based on neutralizing antibodies may be promising therapeutic strategies for treatment of low bone mass in postmenopausal osteoporosis, osteogenesis imperfecta or for osteopenia associated with colitis, anorexia, HIV or chemotherapy. Pre-clinical trials in rat models of postmenopausal [17] and colitis-induced [91] bone loss have successfully inhibited bone loss. Short term treatment in cynomolgous monkeys increased bone mass [16]. Recently, improvements in experimental fracture healing have been reported when treated with sclerostin antibody in both rat 
and cynomolgous monkey models [92]. Clinical studies have also shown that a single injection of AMG-785 (an anti-sclerostin antibody preparation) increased serum markers of bone formation, inhibited markers of bone resorption, and improved bone mass [67] as observed previously in ovariectomized rats [17]. Most recently, Phase II clinical trials of AMG-785 have been completed, and although not published in complete form, a press release reported that AMG-785 treatment of postmenopausal women with low bone mineral density (BMD) significantly increased lumbar spine BMD after 12 months compared to placebo.

\section{Concluding remarks}

In conclusion, there are a number of pathways through which sclerostin is regulated (see Figure 1 for direct influences). Factors that stimulate bone formation, including mechanical loading, systemic PTH and paracrine PTHrP and locally acting factors such as OSM, prostaglandins and hypoxia inhibit sclerostin expression through MEF2-dependent and independent pathways. In this manner, the inhibition of sclerostin may contribute to the bone forming influences of these factors. In contrast, sclerostin is rapidly induced by calcitonin, an effect that may relate to the possible physiological action of calcitonin as a systemic inhibitor of bone formation. Sclerostin expression is also regulated when osteoblast differentiation is modified; this may be mediated by osteoblastic transcription factors, or by local inflammatory mediators. Sex steroid hormones may also regulate osteocytic sclerostin, but at this stage the evidence is still preliminary, and based largely on the regulation of circulating sclerostin levels. The regulation of sclerostin by such a wide range of bone-active 
hormones and cytokines suggests that in those patients with sclerostin

deficiency, the impairment of impact of these factors on bone formation may also contribute to the widespread sclerosis. Local dysregulation of sclerostin by the paracrine signals described above may also play a role in disorders where sclerotic lesions are observed in specific skeletal sites. It is also possible that altered regulation of sclerostin by these, or other factors, may also be involved in pathologies involving calcification of extraskeletal tissues.

The physiological and pharmacological regulation of sclerostin in the osteocyte population, as well as possible regulation of sclerostin in other tissues remains an area with many questions, the answers to this will provide new insights into the mechanisms of bone formation in normal bone formation, in sclerosing disorders of bone, and in the mechanism of action of novel anabolic therapies for bone that inhibit sclerostin.

\section{Figure Legend:}

Figure 1: Multiple paths of influence converging on osteocytic production of sclerostin. Parathyroid hormone (PTH), calcitonin and sex steroid hormones from the bloodstream influence sclerostin expression. Mechanical forces also directly inhibit sclerostin production. Locally-acting cytokines produced by osteocytes themselves, and by osteoblasts (oncostatin M (OSM), parathyroid hormone related protein (PTHrP), prostaglandin $\mathrm{E}_{2}$ ) and the osteoclast (cardiotrophin-1 / CT-1) influence sclerostin production. In turn, this inhibits the activity of bone-forming osteoblasts. 


\section{Acknowledgements}

Thanks to Damien Genetos for helpful information on non-osteocyte specific

expression of sclerostin and to Jack Martin for critical reading of this manuscript.

\section{References}

[1] Balemans W, Ebeling M, Patel N, Van Hul E, Olson P, Dioszegi M, Lacza C, Wuyts W, Van Den Ende J, Willems P, Paes-Alves AF, Hill S, Bueno M, Ramos FJ, Tacconi P, Dikkers FG, Stratakis C, Lindpaintner K, Vickery B, Foernzler D, Van Hul W. Increased bone density in sclerosteosis is due to the deficiency of a novel secreted protein (SOST). Hum Mol Genet 2001;10: 537-43.

[2] Balemans W, Patel N, Ebeling M, Van Hul E, Wuyts W, Lacza C, Dioszegi M, Dikkers FG, Hildering P, Willems PJ, Verheij JB, Lindpaintner K, Vickery B, Foernzler D, Van Hul W. Identification of a $52 \mathrm{~kb}$ deletion downstream of the SOST gene in patients with van Buchem disease. J Med Genet 2002;39: 91-7.

[3] Brunkow ME, Gardner JC, Van Ness J, Paeper BW, Kovacevich BR, Proll S, Skonier JE, Zhao L, Sabo PJ, Fu Y, Alisch RS, Gillett L, Colbert T, Tacconi P, Galas $\mathrm{D}$, Hamersma H, Beighton P, Mulligan J. Bone dysplasia sclerosteosis results from loss of the SOST gene product, a novel cystine knot-containing protein. Am J Hum Genet 2001;68: 577-89.

[4] Lin C, Jiang X, Dai Z, Guo X, Weng T, Wang J, Li Y, Feng G, Gao X, He L. Sclerostin mediates bone response to mechanical unloading through antagonizing Wnt/beta-catenin signaling. J Bone Miner Res 2009;24: 1651-61.

[5] Li X, Ominsky MS, Niu QT, Sun N, Daugherty B, D'Agostin D, Kurahara C, Gao Y, Cao J, Gong J, Asuncion F, Barrero M, Warmington K, Dwyer D, Stolina M, Morony S, Sarosi I, Kostenuik PJ, Lacey DL, Simonet WS, Ke HZ, Paszty C. Targeted deletion of the sclerostin gene in mice results in increased bone formation and bone strength. J Bone Miner Res 2008;23: 860-9.

[6] Loots GG, Kneissel M, Keller H, Baptist M, Chang J, Collette NM, Ovcharenko D, Plajzer-Frick I, Rubin EM. Genomic deletion of a long-range bone enhancer misregulates sclerostin in Van Buchem disease. Genome Res 2005;15: 92835 .

[7] Li X, Zhang Y, Kang H, Liu W, Liu P, Zhang J, Harris SE, Wu D. Sclerostin binds to LRP5/6 and antagonizes canonical Wnt signaling. J Biol Chem 2005;280: 19883-7.

[8] Semenov M, Tamai K, He X. SOST is a ligand for LRP5/LRP6 and a Wnt signaling inhibitor. J Biol Chem 2005;280: 26770-5.

[9] Gaudio A, Pennisi P, Bratengeier C, Torrisi V, Lindner B, Mangiafico RA, Pulvirenti I, Hawa G, Tringali G, Fiore CE. Increased sclerostin serum levels associated with bone formation and resorption markers in patients with immobilization-induced bone loss. J Clin Endocrinol Metab 2010;95: 2248-53.

[10] Poole KE, van Bezooijen RL, Loveridge N, Hamersma H, Papapoulos SE, Lowik CW, Reeve J. Sclerostin is a delayed secreted product of osteocytes that inhibits bone formation. Faseb J 2005;19: 1842-4. 
[11] van Bezooijen RL, Roelen BA, Visser A, van der Wee-Pals L, de Wilt E, Karperien M, Hamersma H, Papapoulos SE, ten Dijke P, Lowik CW. Sclerostin is an osteocyte-expressed negative regulator of bone formation, but not a classical BMP antagonist. J Exp Med 2004;199: 805-14.

[12] Keller H, Kneissel M. SOST is a target gene for PTH in bone. Bone 2005;37: $148-58$.

[13] Zhu D, Mackenzie NC, Millan JL, Farquharson C, Macrae VE. The Appearance and Modulation of Osteocyte Marker Expression during Calcification of Vascular Smooth Muscle Cells. PLoS One 2011;6: e19595.

[14] Winkler DG, Sutherland MK, Geoghegan JC, Yu C, Hayes T, Skonier JE, Shpektor D, Jonas M, Kovacevich BR, Staehling-Hampton K, Appleby M, Brunkow ME, Latham JA. Osteocyte control of bone formation via sclerostin, a novel BMP antagonist. Embo J 2003;22: 6267-76.

[15] Sawakami K, Robling AG, Ai M, Pitner ND, Liu D, Warden SJ, Li J, Maye P, Rowe DW, Duncan RL, Warman ML, Turner CH. The Wnt co-receptor LRP5 is essential for skeletal mechanotransduction but not for the anabolic bone response to parathyroid hormone treatment. J Biol Chem 2006;281: 23698-711.

[16] Ominsky MS, Vlasseros F, Jolette J, Smith SY, Stouch B, Doellgast G, Gong J, Gao Y, Cao J, Graham K, Tipton B, Cai J, Deshpande R, Zhou L, Hale MD, Lightwood DJ, Henry AJ, Popplewell AG, Moore AR, Robinson MK, Lacey DL, Simonet WS, Paszty C. Two doses of sclerostin antibody in cynomolgus monkeys increases bone formation, bone mineral density, and bone strength. J Bone Miner Res 2010;25: 948-59.

[17] Li X, Ominsky MS, Warmington KS, Morony S, Gong J, Cao J, Gao Y, Shalhoub V, Tipton B, Haldankar R, Chen Q, Winters A, Boone T, Geng Z, Niu QT, Ke HZ, Kostenuik PJ, Simonet WS, Lacey DL, Paszty C. Sclerostin antibody treatment increases bone formation, bone mass, and bone strength in a rat model of postmenopausal osteoporosis. J Bone Miner Res 2009;24: 578-88.

[18] de Souza RL, Pitsillides AA, Lanyon LE, Skerry TM, Chenu C. Sympathetic nervous system does not mediate the load-induced cortical new bone formation. $\mathrm{J}$ Bone Miner Res 2005;20: 2159-68.

[19] Robling AG, Bellido T, Turner CH. Mechanical stimulation in vivo reduces osteocyte expression of sclerostin. J Musculoskelet Neuronal Interact 2006;6: 354.

[20] Moustafa A, Sugiyama T, Prasad J, Zaman G, Gross TS, Lanyon LE, Price JS. Mechanical loading-related changes in osteocyte sclerostin expression in mice are more closely associated with the subsequent osteogenic response than the peak strains engendered. Osteoporos Int 2011; In Press.

[21] Tatsumi S, Ishii K, Amizuka N, Li M, Kobayashi T, Kohno K, Ito M, Takeshita S, Ikeda K. Targeted ablation of osteocytes induces osteoporosis with defective mechanotransduction. Cell Metab 2007;5: 464-75.

[22] Tian X, Jee WS, Li X, Paszty C, Ke HZ. Sclerostin antibody increases bone mass by stimulating bone formation and inhibiting bone resorption in a hindlimbimmobilization rat model. Bone 2011;48: 197-201.

[23] Papanicolaou SE, Phipps RJ, Fyhrie DP, Genetos DC. Modulation of sclerostin expression by mechanical loading and bone morphogenetic proteins in osteogenic cells. Biorheology 2009;46: 389-99.

[24] Niikura T, Hak DJ, Reddi AH. Global gene profiling reveals a downregulation of BMP gene expression in experimental atrophic nonunions compared to standard healing fractures. J Orthop Res 2006;24: 1463-71. 
[25] Hak DJ, Makino T, Niikura T, Hazelwood SJ, Curtiss S, Reddi AH. Recombinant human BMP-7 effectively prevents non-union in both young and old rats. J Orthop Res 2006;24: 11-20.

[26] Mantila Roosa SM, Liu Y, Turner CH. Gene expression patterns in bone following mechanical loading. J Bone Miner Res 2011;26: 100-12.

[27] Goltzman D, G.N. Hendy. Principles and Practice of Endocrinology and Metabolism. Philadelphia: J.B. Lippincott Co.; 1995.

[28] Teitelbaum SL. Bone resorption by osteoclasts. Science 2000;289: 1504-8.

[29] Rodan GA, Martin TJ. Role of osteoblasts in hormonal control of bone resorption--a hypothesis. Calcif Tissue Int 1981;33: 349-51.

[30] Liu BY, Guo J, Lanske B, Divieti P, Kronenberg HM, Bringhurst FR. Conditionally immortalized murine bone marrow stromal cells mediate parathyroid hormone-dependent osteoclastogenesis in vitro. Endocrinology 1998;139: 1952-64. [31] Suda T, Takahashi N, Udagawa N, Jimi E, Gillespie MT, Martin TJ.

Modulation of osteoclast differentiation and function by the new members of the tumor necrosis factor receptor and ligand families. Endocr Rev 1999;20: 345-57. [32] Nishida S, Yamaguchi A, Tanizawa T, Endo N, Mashiba T, Uchiyama Y, Suda T, Yoshiki S, Takahashi HE. Increased bone formation by intermittent parathyroid hormone administration is due to the stimulation of proliferation and differentiation of osteoprogenitor cells in bone marrow. Bone 1994;15: 717-23.

[33] Pettway GJ, Meganck JA, Koh AJ, Keller ET, Goldstein SA, McCauley LK. Parathyroid hormone mediates bone growth through the regulation of osteoblast proliferation and differentiation. Bone 2008;42: 806-18.

[34] Jilka RL, Weinstein RS, Bellido T, Roberson P, Parfitt AM, Manolagas SC. Increased bone formation by prevention of osteoblast apoptosis with parathyroid hormone. J Clin Invest 1999;104: 439-46.

[35] Bellido T, Ali AA, Plotkin LI, Fu Q, Gubrij I, Roberson PK, Weinstein RS, O'Brien CA, Manolagas SC, Jilka RL. Proteasomal degradation of Runx 2 shortens parathyroid hormone-induced anti-apoptotic signaling in osteoblasts. A putative explanation for why intermittent administration is needed for bone anabolism. J Biol Chem 2003;278: 50259-72.

[36] Jilka RL. Molecular and cellular mechanisms of the anabolic effect of intermittent PTH. Bone 2007;40: 1434-46.

[37] Dobnig H, Turner RT. Evidence that intermittent treatment with parathyroid hormone increases bone formation in adult rats by activation of bone lining cells. Endocrinology 1995;136: 3632-8.

[38] Neer RM, Arnaud CD, Zanchetta JR, Prince R, Gaich GA, Reginster JY, Hodsman AB, Eriksen EF, Ish-Shalom S, Genant HK, Wang O, Mitlak BH. Effect of parathyroid hormone (1-34) on fractures and bone mineral density in postmenopausal women with osteoporosis. N Engl J Med 2001;344: 1434-41.

[39] Jiang Y, Zhao JJ, Mitlak BH, Wang O, Genant HK, Eriksen EF. Recombinant human parathyroid hormone (1-34) [teriparatide] improves both cortical and cancellous bone structure. J Bone Miner Res 2003;18: 1932-41.

[40] Bellido T, Ali AA, Gubrij I, Plotkin LI, Fu Q, O'Brien CA, Manolagas SC, Jilka RL. Chronic elevation of parathyroid hormone in mice reduces expression of sclerostin by osteocytes: a novel mechanism for hormonal control of osteoblastogenesis. Endocrinology 2005;146: 4577-83.

[41] Ma YL, Cain RL, Halladay DL, Yang X, Zeng Q, Miles RR, Chandrasekhar S, Martin TJ, Onyia JE. Catabolic effects of continuous human PTH (1--38) in vivo is 
associated with sustained stimulation of RANKL and inhibition of osteoprotegerin and gene-associated bone formation. Endocrinology 2001;142: 4047-54.

[42] Mirza FS, Padhi ID, Raisz LG, Lorenzo JA. Serum sclerostin levels negatively correlate with parathyroid hormone levels and free estrogen index in postmenopausal women. J Clin Endocrinol Metab 2010;95: 1991-7.

[43] Staehling-Hampton K, Proll S, Paeper BW, Zhao L, Charmley P, Brown A, Gardner JC, Galas D, Schatzman RC, Beighton P, Papapoulos S, Hamersma H, Brunkow ME. A 52-kb deletion in the SOST-MEOX1 intergenic region on 17q12q21 is associated with van Buchem disease in the Dutch population. Am J Med Genet 2002;110: 144-52.

[44] Leupin O, Kramer I, Collette NM, Loots GG, Natt F, Kneissel M, Keller H. Control of the SOST bone enhancer by PTH using MEF2 transcription factors. J Bone Miner Res 2007;22: 1957-67.

[45] Olson EN, Perry M, Schulz RA. Regulation of muscle differentiation by the MEF2 family of MADS box transcription factors. Dev Biol 1995;172: 2-14.

[46] McKinsey TA, Zhang CL, Olson EN. MEF2: a calcium-dependent regulator of cell division, differentiation and death. Trends Biochem Sci 2002;27: 40-7.

[47] Arnold MA, Kim Y, Czubryt MP, Phan D, McAnally J, Qi X, Shelton JM, Richardson JA, Bassel-Duby R, Olson EN. MEF2C transcription factor controls chondrocyte hypertrophy and bone development. Dev Cell 2007;12: 377-89.

[48] Miao D, He B, Jiang Y, Kobayashi T, Soroceanu MA, Zhao J, Su H, Tong X, Amizuka N, Gupta A, Genant HK, Kronenberg HM, Goltzman D, Karaplis AC.

Osteoblast-derived PTHrP is a potent endogenous bone anabolic agent that modifies the therapeutic efficacy of administered PTH 1-34. J Clin Invest 2005;115: 2402-11. [49] Sugiyama T, Saxon LK, Zaman G, Moustafa A, Sunters A, Price JS, Lanyon LE. Mechanical loading enhances the anabolic effects of intermittent parathyroid hormone (1-34) on trabecular and cortical bone in mice. Bone 2008;43: 238-48. [50] Powell WF, Jr., Barry KJ, Tulum I, Kobayashi T, Harris SE, Bringhurst FR, Pajevic PD. Targeted ablation of the PTH/PTHrP receptor in osteocytes impairs bone structure and homeostatic calcemic responses. J Endocrinol 2011;209: 21-32.

[51] Schipani E, Lanske B, Hunzelman J, Luz A, Kovacs CS, Lee K, Pirro A, Kronenberg HM, Juppner H. Targeted expression of constitutively active receptors for parathyroid hormone and parathyroid hormone-related peptide delays endochondral bone formation and rescues mice that lack parathyroid hormone-related peptide. Proc Natl Acad Sci U S A 1997;94: 13689-94.

[52] Calvi LM, Sims NA, Hunzelman JL, Knight MC, Giovannetti A, Saxton JM, Kronenberg HM, Baron R, Schipani E. Activated parathyroid hormone/parathyroid hormone-related protein receptor in osteoblastic cells differentially affects cortical and trabecular bone. J Clin Invest 2001;107: 277-86.

[53] Kramer I, Loots GG, Studer A, Keller H, Kneissel M. Parathyroid Hormone (PTH) Induced Bone Gain is Blunted in SOST Overexpressing and Deficient Mice. J Bone Miner Res 2010;25: 178-189.

[54] Copp DH, Davidson, A.G.F., Cheney, B.A. Evidence for a new parathyroid hormone which lowers blood calcium. Proc. Canad. Fed. Biol. Soc 1961;4.

[55] Friedman J, Raisz LG. Thyrocalcitonin: inhibitor of bone resorption in tissue culture. Science 1965;150: 1465-7.

[56] Martin TJ, Robinson CJ, MacIntyre I. The mode of action of thyrocalcitonin. Lancet 1966;1: 900-2. 
[57] Quinn JM, Morfis M, Lam MH, Elliott J, Kartsogiannis V, Williams ED, Gillespie MT, Martin TJ, Sexton PM. Calcitonin receptor antibodies in the identification of osteoclasts. Bone 1999;25: 1-8.

[58] Gooi JH, Pompolo S, Karsdal MA, Kulkarni NH, Kalajzic I, McAhren SH, Han B, Onyia JE, Ho PW, Gillespie MT, Walsh NC, Chia LY, Quinn JM, Martin TJ, Sims NA. Calcitonin impairs the anabolic effect of PTH in young rats and stimulates expression of sclerostin by osteocytes. Bone 2010;46: 1486-97.

[59] Paic F, Igwe JC, Nori R, Kronenberg MS, Franceschetti T, Harrington P, Kuo L, Shin DG, Rowe DW, Harris SE, Kalajzic I. Identification of differentially expressed genes between osteoblasts and osteocytes. Bone 2009;45: 682-

92.

[60] Hoff AO, Catala-Lehnen P, Thomas PM, Priemel M, Rueger JM, Nasonkin I, Bradley A, Hughes MR, Ordonez N, Cote GJ, Amling M, Gagel RF. Increased bone mass is an unexpected phenotype associated with deletion of the calcitonin gene. $\mathrm{J}$ Clin Invest 2002;110: 1849-57.

[61] Schinke T, Liese S, Priemel M, Haberland M, Schilling AF, Catala-Lehnen P, Blicharski D, Rueger JM, Gagel RF, Emeson RB, Amling M. Decreased bone formation and osteopenia in mice lacking alpha-calcitonin gene-related peptide. J Bone Miner Res 2004;19: 2049-56.

[62] Dacquin R, Davey RA, Laplace C, Levasseur R, Morris HA, Goldring SR, Gebre-Medhin S, Galson DL, Zajac JD, Karsenty G. Amylin inhibits bone resorption while the calcitonin receptor controls bone formation in vivo. J Cell Biol 2004;164: 509-14.

[63] Davey RA, Turner AG, McManus JF, Chiu WS, Tjahyono F, Moore AJ, Atkins GJ, Anderson PH, Ma C, Glatt V, MacLean HE, Vincent C, Bouxsein M, Morris HA, Findlay DM, Zajac JD. Calcitonin receptor plays a physiological role to protect against hypercalcemia in mice. J Bone Miner Res 2008;23: 1182-93.

[64] Keller JH, Huebner AK, Catala-Lehnen P, Schinke T, Amling M. High bone mass due to increased bone formation in mice lacking the calcitonin receptor. J Bone Miner Res 2008;23: s171.

[65] Riggs BL, Khosla S, Melton LJ, 3rd. Sex steroids and the construction and conservation of the adult skeleton. Endocr Rev 2002;23: 279-302.

[66] Modder UI, Clowes JA, Hoey K, Peterson JM, McCready L, Oursler MJ, Riggs BL, Khosla S. Regulation of circulating sclerostin levels by sex steroids in women and in men. J Bone Miner Res 2011;26: 27-34.

[67] Padhi D, Jang G, Stouch B, Fang L, Posvar E. Single-dose, placebocontrolled, randomized study of AMG 785, a sclerostin monoclonal antibody. J Bone Miner Res 2010;26: 19-26.

[68] Sims NA, Dupont S, Krust A, Clement-Lacroix P, Minet D, Resche-Rigon M, Gaillard-Kelly M, Baron R. Deletion of estrogen receptors reveals a regulatory role for estrogen receptors-beta in bone remodeling in females but not in males. Bone 2002;30: 18-25.

[69] Moustafa A, Sugiyama T, Saxon LK, Zaman G, Sunters A, Armstrong VJ, Javaheri B, Lanyon LE, Price JS. The mouse fibula as a suitable bone for the study of functional adaptation to mechanical loading. Bone 2009;44: 930-5.

[70] Callewaert F, Bakker A, Schrooten J, Van Meerbeek B, Verhoeven G, Boonen $\mathrm{S}$, Vanderschueren D. Androgen receptor disruption increases the osteogenic response to mechanical loading in male mice. J Bone Miner Res 2010;25: 124-31. 
[71] Sims NA, Gooi JH. Bone remodeling: Multiple cellular interactions required for coupling of bone formation and resorption. Semin Cell Dev Biol 2008; 19: 444-51.

[72] Martin TJ, Sims NA. Osteoclast-derived activity in the coupling of bone formation to resorption. Trends Mol Med 2005;11: 76-81.

[73] Walker EC, McGregor NE, Poulton IJ, Solano M, Pompolo S, Fernandes TJ, Constable MJ, Nicholson GC, Zhang JG, Nicola NA, Gillespie MT, Martin TJ, Sims NA. Oncostatin M promotes bone formation independently of resorption when signaling through leukemia inhibitory factor receptor in mice. J Clin Invest 2010;120: 582-92.

[74] Walker EC, McGregor NE, Poulton IJ, Pompolo S, Allan EH, Quinn JM, Gillespie MT, Martin TJ, Sims NA. Cardiotrophin-1 is an osteoclast-derived stimulus of bone formation required for normal bone remodeling. J Bone Miner Res 2008;23: 2025-32.

[75] Cornish J, Callon K, King A, Edgar S, Reid IR. The effect of leukemia inhibitory factor on bone in vivo. Endocrinology 1993;132: 1359-66.

[76] Allan EH, Hilton DJ, Brown MA, Evely RS, Yumita S, Metcalf D, Gough NM, Ng KW, Nicola NA, Martin TJ. Osteoblasts display receptors for and responses to leukemia-inhibitory factor. J Cell Physiol 1990;145: 110-9.

[77] Sims NA, Walsh NC. GP130 cytokines and bone remodelling in health and disease. BMB Rep 2010;43: 513-23.

[78] Poulton IJ, McGregor NE, Pompolo S, Walker EC, Sims NA. Contrasting roles of leukemia inhibitory factor (LIF) in neonatal bone development and adult bone remodeling involve regulation of vascular endothelial growth factor (VEGF).

submitted.

[79] McGregor NE, Poulton IJ, Walker EC, Pompolo S, Quinn JM, Martin TJ, Sims NA. Ciliary neurotrophic factor inhibits bone formation and plays a sex-specific role in bone growth and remodeling. Calcif Tissue Int 2010;86: 261-70.

[80] Blackwell KA, Raisz LG, Pilbeam CC. Prostaglandins in bone: bad cop, good cop? Trends in endocrinology and metabolism: TEM 2010;21: 294-301.

[81] Genetos DC, Yellowley CE, Loots GG. Prostaglandin E2 signals through PTGER2 to regulate sclerostin expression. PLoS One 2011;6: e17772.

[82] Genetos DC, Toupadakis CA, Raheja LF, Wong A, Papanicolaou SE, Fyhrie DP, Loots GG, Yellowley CE. Hypoxia decreases sclerostin expression and increases Wnt signaling in osteoblasts. J Cell Biochem 2010;110: 457-67.

[83] Vincent C, Findlay DM, Welldon KJ, Wijenayaka AR, Zheng TS, Haynes DR, Fazzalari NL, Evdokiou A, Atkins GJ. Pro-inflammatory cytokines TNF-related weak inducer of apoptosis (TWEAK) and TNFalpha induce the mitogen-activated protein kinase (MAPK)-dependent expression of sclerostin in human osteoblasts. J Bone Miner Res 2009;24: 1434-49.

[84] Walsh NC, Gravallese EM. Bone remodelling in rheumatic diseases: a question of balance. Immunol. Rev. 2010;233: 301-312.

[85] Walsh NC, Reinwald S, Manning CA, Condon KW, Iwata K, Burr DB, Gravallese EM. Osteoblast function is compromised at sites of focal bone erosion in inflammatory arthritis. J Bone Miner Res 2009;24: 1572-85.

[86] Quach JM, Walker EC, Allan E, Solano M, Yokoyama A, Kato S, Sims NA, Gillespie MT, Martin TJ. Zinc finger protein 467 is a novel regulator of osteoblast and adipocyte commitment. J Biol Chem 2011;286: 4186-98.

[87] Allan EH, Hausler KD, Wei T, Gooi JH, Quinn JM, Crimeen-Irwin B, Pompolo S, Sims NA, Gillespie MT, Onyia JE, Martin TJ. EphrinB2 regulation by 
PTH and PTHrP revealed by molecular profiling in differentiating osteoblasts. J Bone Miner Res 2008;23: 1170-81.

[88] Martin TJ, Allan EH, Ho PW, Gooi JH, Quinn JM, Gillespie MT, Krasnoperov V, Sims NA. Communication Between EphrinB2 and EphB4 Within the Osteoblast Lineage. Adv Exp Med Biol 2010;658: 51-60.

[89] Nakashima K, Zhou X, Kunkel G, Zhang Z, Deng JM, Behringer RR, de Crombrugghe $\mathrm{B}$. The novel zinc finger-containing transcription factor osterix is required for osteoblast differentiation and bone formation. Cell 2002;108: 17-29. [90] Yang F, Tang W, So S, de Crombrugghe B, Zhang C. Sclerostin is a direct target of osteoblast-specific transcription factor osterix. Biochem Biophys Res Commun 2010;400: 684-8.

[91] Eddleston A, Marenzana M, Moore AR, Stephens P, Muzylak M, Marshall D, Robinson MK. A short treatment with an antibody to sclerostin can inhibit bone loss in an ongoing model of colitis. J Bone Miner Res 2009;24: 1662-71.

[92] Ominsky MS, Li C, Li X, Tan HL, Lee E, Barrero M, Asuncion FJ, Dwyer D, Han CY, Vlasseros F, Samadfam R, Jolette J, Smith SY, Stolina M, Lacey DL, Simonet WS, Paszty C, Li G, Ke HZ. Inhibition of sclerostin by monoclonal antibody enhances bone healing and improves bone density and strength of nonfractured bones. J Bone Miner Res 2011;26: 1012-21.

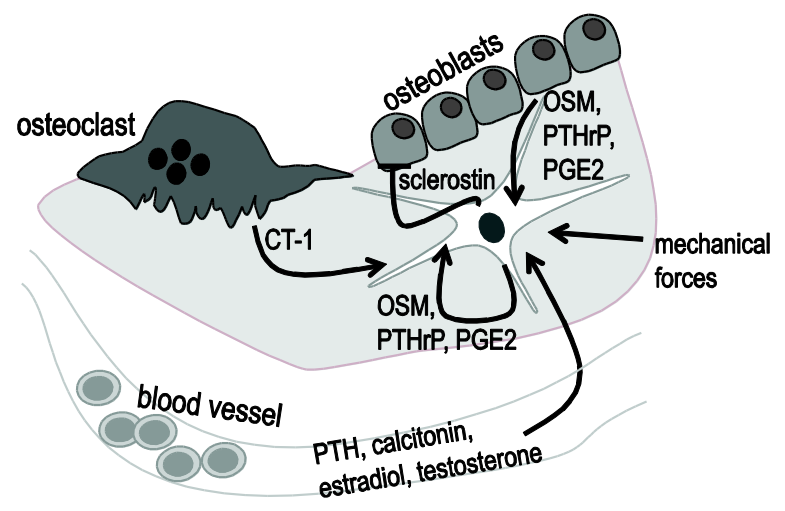

